\title{
An icteric newborn with bad obstetric history
}

\section{Mohammod Shahidullah, M. A. Mannan, Sanjoy Kumer Dey, Sadeka Choudhury Moni, Mohammad Kamrul Hassan Shabuj, Ismat Jahan and Nazmus Sihan}

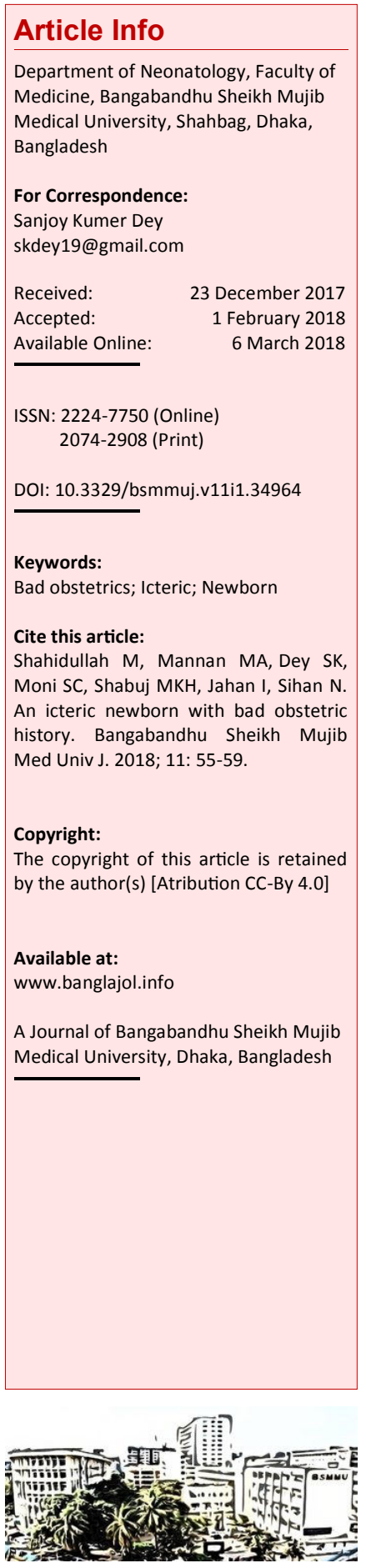

\section{Case Presentation}

Dr. Shabnam Shoyeb: A 34 week preterm baby was admitted with the complaints of respiratory distress soon after birth. The mother had bad obstetric history. She is having the fifth gravida with the first two alive and healthy who were born by the normal vaginal delivery at home. The third child was born with severe jaundice and was treated by exchange transfusion. Subsequently the baby developed bilirubin encephalopathy. Then the baby developed cerebral palsy and ultimately died due to aspiration pneumonia at the age of 2.5 years.

Her first three pregnancies were not on any antenatal check-up by the health care provider due to poor socio-economic background and illiteracy. She enrolled herself under regular antenatal care at a local private hospital for the first time during the fourth pregnancy but it was ended with intrauterine death most probably due to Rh sensitization at 36 weeks of gestation at the hospital by lower segment cesarean section. The antibody titer was not done during the $4^{\text {th }}$ pregnancy but she took anti -D therapy after the delivery of dead fetus for the first time.

During this pregnancy, she was referred to the Bangabandhu Sheikh Mujib Medical University at her $10^{\text {th }}$ week of gestation as a high-risk pregnancy in view of better obstetric and neonatal outcome. She was also diagnosed as gestational diabetes mellitus at her $14^{\text {th }}$ weeks of gestation and was treated with insulin.

Thorough history, clinical examination and laboratory investigations were done during the admission into the fetomaternal unit. History and laboratory test revealed her blood group as $\mathrm{B} \mathrm{Rh}$ negative and her husband's as B Rh positive. The antibody titer at 10 weeks of gestation was found above the critical value. The antibody titer was repeated accordingly and it showed rising pattern.

The fetal condition was closely monitored using ultrasonogram. So, the pregnancy was continuing in view of the absence of evidence of fetal hydrops on ultrasonogram. It was suspected as a case of pregnancy with $\mathrm{Rh}$ isoimmunisation. On the basis of raised antibody titer and bad obstetric history, she was counseled by neonatologist about the possible outcome of the current pregnancy and undergone emergency lower uterine cesarean section at 34 weeks of pregnancy after ensuring antenatal corticosteroid 7 days prior to delivery.

A male newborn weighing 2,800 $\mathrm{g}$ was born with the APGAR score 7 in the $1^{\text {st }}$ min and 9 in the $5^{\text {th }}$ min respectively, and the newborn was shifted for better and further management to the Neonatal Intensive Care Unit without any delay.

Soon after delivery, the baby developed respiratory distress requiring oxygen supplementation along with other standard newborn care. He was anemic but not edematous. No hepatosplenomegaly was found during the earlier examination. The blood samples were taken from the umbilical cord. The newborn's blood group was ' $\mathrm{O}$ ' positive. The hemoglobin level was $8.7 \mathrm{~g} / \mathrm{dL}$. The total serum bilirubin level was $8.0 \mathrm{mg} / \mathrm{dL}$. The direct antiglobulin test was positive. The peripheral smear showed anisopoikilocytosis of red cells with abundant polychromatic cells and relative lymphocytosis with eosinophilia.

In view of family history, critically raised antibody titer and highly suggestive cord blood report infant's blood was removed and replaced with fresh ' $\mathrm{O}$ ' negative whole blood compatible with mother's serum at the age of 15 hours with all aseptic precaution. Both pre and post transfusion work up were done along with close clinical monitoring and single surface phototherapy. Single surface phototherapy was omitted at the age of 72 hours as serum bilirubin was declining and it was $7.8 \mathrm{mg} / \mathrm{dL}$. Subsequently during neonatal course, baby developed twice episodes of rebound bilirubinemia which required treatment with phototherapy. The serum glycemic and electrolyte status of the baby were within the normal range throughout the neonatal course.

Follow-up hemoglobin and bilirubin level at the age of ninth postnatal age were $13.1 \mathrm{~g} / \mathrm{dL}$ and $10.7 \mathrm{mg} / \mathrm{dL}$ respectively. The baby was discharged with stable condition, exclusive breast feeding on demand and advice for the follow-up. 


\begin{tabular}{|c|c|}
\hline \multicolumn{2}{|c|}{ Table I } \\
\hline \multicolumn{2}{|c|}{ Laboratory investigations } \\
\hline \multicolumn{2}{|c|}{ Antenatal investigation of the mother } \\
\hline Blood group & B negative \\
\hline \multicolumn{2}{|l|}{ Antibody titer } \\
\hline At booking & $1: 16$ \\
\hline 22nd week & $1: 32$ \\
\hline $26^{\text {th }}$ week & $1: 64$ \\
\hline $30^{\text {th }}$ week & $1: 256$ \\
\hline \multicolumn{2}{|l|}{ Cord blood investigation } \\
\hline Blood group & B positive \\
\hline Coombs test & Positive \\
\hline Hemoglobin level (g/dL) & 8.7 \\
\hline Peripheral blood film & $\begin{array}{l}\text { Normocytic normochromic anemia } \\
\text { with relative lymphocytosis with } \\
\text { eosinophilia }\end{array}$ \\
\hline Reticulocyte (\%) & 2.1 \\
\hline Serum bilirubin $(\mathrm{mg} / \mathrm{dL})$ & 8.0 \\
\hline \multicolumn{2}{|l|}{ Post-exchange investigation } \\
\hline Hemoglobin level (g/dL) & 11.9 \\
\hline Serum bilirubin (mg/dL) & 4.3 \\
\hline Serum sodium (mmol/L) & 144 \\
\hline Serum potassium (mmol/L) & 4 \\
\hline Serum calcium (mg/dL) & 7.8 \\
\hline Random blood sugar (mmol/L) & 6.5 \\
\hline
\end{tabular}

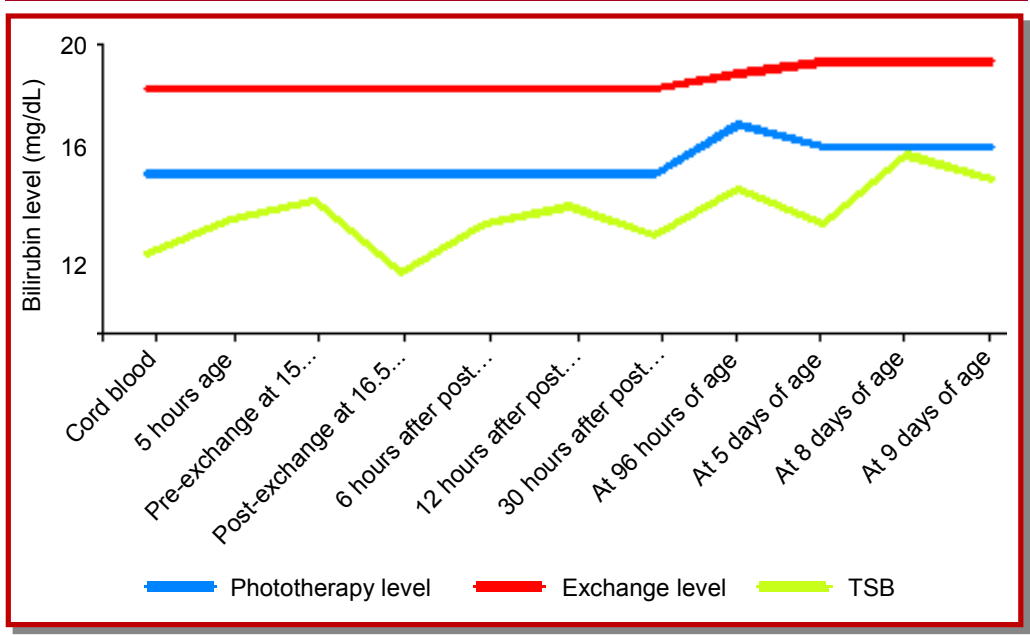

Figure 1: Bilirubin trends

\section{Provisional Diagnosis}

Hemolytic disease of the neonate due to $\mathrm{Rh}$ isoimmunization

\section{Differential Diagnosis}

Dr. Shabnam: The history, clinical examination, antenatal workup and cord investigations were so obvious that no differential diagnosis could be made.

\section{Shoyeb's Diagnosis}

Hemolytic disease of the neonate due to $\mathrm{Rh}$ isoimmunization

\section{Discussion}

Dr. Afshana Jahan: What is Rh isoimmunization and how does it happen?

Dr. Md. Nazmus Sihan: $\mathrm{Rh}$ isoimmunization is characterized by the formation of autoantibody if a woman of Rh negative blood group gets exposed to $\mathrm{Rh}$ positive blood. A difference in Rh type between an expectant mother and her baby, is a way when $\mathrm{Rh}$ isoimmunization can complicate the pregnancy.

The fetal blood, during pregnancy, can cross into the maternal bloodstream by feto-maternal hemorrhage. The primary immune response can be induced if the Rh negative blood gets exposed to even $1 \mathrm{~mL}$ of $\mathrm{Rh}$ positive red cells. $.1,2$ Exposure of maternal Rh negative blood cells to the baby of $\mathrm{Rh}$ positive blood cells leads to the formation of antibodies against $\mathrm{Rh}$ negative blood cells. These antibodies can cross the placenta and attack the baby's red blood cells resulting in hemolytic anemia within the baby. This Rh isoimmunization usually does not cause any illness during the first pregnancy as the baby is born before antibody formation. But the condition is more likely to be serious in second or subsequent pregnancies (if the baby is $\mathrm{Rh}$ positive) as the Rh antibodies are there within the mother's body which was previously developed.

Dr. Tapash Chowdhury: Who is at risk of Rh isoimmunization?

Dr. Sihan: In case of inherited Rh factor, the baby has the $50 \%$ or more chance to have Rh positive blood group in case of $\mathrm{Rh}$ negative mother and $\mathrm{Rh}$ positive father. A Rh negative mother bearing an Rh positive fetus is prone to develop $\mathrm{Rh}$ isoimmunization.

The risk of $\mathrm{Rh}$ isoimmunization is higher if the $\mathrm{Rh}$ negative mother was exposed to $\mathrm{Rh}$ positive blood before the pregnancy. For instance, exposure during an earlier pregnancy (including the spontaneous and elective abortions), ectopic pregnancy, vaginal bleeding or amniotic discharge, previous invasive procedures (such as amniocentesis, cordocentesis, chorionic villous sampling) can result in the isoimmunization effect in the fetus or newborn.1 The history of mismatched blood transfusion or the administration of $\mathrm{Rh} \operatorname{IgG}$ can also increase the chance of isoimmunization. $\underline{1}$ 
Dr. Mokshed Alam: What are the clinical signs and symptoms of hemolytic disease of the newborn due to Rh isoimmunization? What are the clinical features present in this case?

Dr. Shabnam: In newborn, the hemolytic disease is associated with varying degree of anemia and jaundice. Due to rapid hemolysis, there is an increased fetal unconjugated bilirubin level leading to the appearance of jaundice that appears from the first 24 hours of life. In utero, the excessive unconjugated bilirubin is cleared off by the placenta and the fetus is not affected. But following delivery, as protective mechanism by placenta is withdrawn; there is a rapid surge in the serum bilirubin level. As the newborn's liver fails to conjugate the huge load of unconjugated bilirubin, it gets deposited in the brain especially when the serum level is more than $340 \mu \mathrm{mol} / \mathrm{L}$ (in term infant) leading to the potential neurological damage named kernicterus. $\frac{2,3}{3}$ However, only anemia in the absence of jaundice can also be the clinical presentation of Rh-hemolytic anemia of the newborn. $\underline{4}$ Potentially lethal comorbidities associated with the hemolytic anemia of the newborn that need attention of clinicians are hypoxia, acidosis and hypoglycemia. $\underline{1,2}$ Affected newborn may develop hepatosplenomegaly. The severe form of hemolytic anemia may result in hydrops fetalis and features of the heart failure. Around $20-25 \%$ of the $\mathrm{Rh}$ isoimmunisation cases may lead to severe hemolytic anemia which is fatal.2, In this particular case, anemia was present since birth.

Dr. Humaira Akhter: What is the incidence of $\mathrm{Rh}$ isoimmunization?

Dr. Sihan: Due to regular antenatal follow-up and routine administration of postnatal prophylactic anti-D immunoglobulin to all $\mathrm{Rh}$ negative mothers, the incidence of Rh-hemolytic disease of newborn has decreased dramatically in developed countries.., 6 According to recent data, anti-D positivity in women of reproductive age has been dropped down to as low as $2.6 / 1,000$ samples. 5,6 The trend of having nuclear families and improved perinatal care also contributed significantly towards this decline in morbidity and mortality from $\mathrm{Rh}$ hemolytic disease of a newborn.? However, several studies done in Bangladesh shows that there are high incidence of $\mathrm{Rh}$ isoimmunization due to large number of unbooked pregnancy and home delivery. It is about 5.4 to $15 \% . \underline{8-10}$

Dr. Saiful Islam: Is there any screening test to detect $\mathrm{Rh}$ isoimmunization antenatally? How the Rh isoimmunization can be detected during pregnancy?

Dr. Sihan: If a mother is Rh negative, an antibody screening is advised to check whether $\mathrm{Rh}$ antibodies are present in the blood or not. If the antibody titer is high $(>1: 16)$ that means the mother is already exposed to the Rh positive blood before and is at risk for $\mathrm{Rh}$ isoimmunization in the fetus. If both the parents are having $\mathrm{Rh}$ negative blood group, the baby has no chance of having Rh positive blood group resulting no risk of $\mathrm{Rh}$ isoimmunization. However, if the baby's father has Rh positive blood group, the baby has $50 \%$ or more chance of having Rh positive blood. Therefore, the fetus is at high-risk of developing $\mathrm{Rh}$ isoimmunization. In an advanced center, amniocentesis can be done in doubtful case to confirm the fetus's Rh status.

If the $\mathrm{Rh}$ incompatibility is known or suspected, then the serial Rh antibodies (at booking then at 20 weeks gestation, 24 and 28 weeks of gestation respectively) are advised during pregnancy.

The antibody level also can suggest the severity of hemolytic anemia in the fetus. Higher level or progressive rising of antibody titers are suggestive of more severe hemolytic anemia. 11 Presence of edema or the evidence of hydrops fetalis can be assessed by the routine ultrasonogram. Doppler ultrasound is even more useful to detect the blood flow through the artery and passive evidence of anemia.11

Dr. Debabrata Roy: How can Rh isoimmunization be prevented?

Dr. Mohammad Kamrul Hassan Shabuj: The Rh incompatibility can be prevented by administering anti-D. Once the mother is sensitized and formed the $\mathrm{Rh}$ antibodies, then no medicine is required to prevent the condition.

A woman having $\mathrm{Rh}$ negative blood must administer anti-D during the pregnancy (28 weeks gestation) and after each pregnancy (72 hours after delivery) or after any other event (abortion, miscarriage, ectopic pregnancy, amniocentesis, chorionic villus sampling) that may expose her Rh negative blood cells to Rh positive blood cells. $\underline{11}$ By routine antenatal care one can reduce or prevent the events linked to $\mathrm{Rh}$ isoimmunization by serial antibody estimation and ultrasonography.

Fetal RH D genotype can be determined by the presence of cell free DNA in the maternal plasma. Recent study suggests that the prediction of fetal D blood group along with the targeted antenatal anti$\mathrm{D}$ prophylaxis is the optimal antenatal management. 12

Dr. Suman Sarkar: What to do if the antenatal titer is found to be high and the fetus has developed the signs of hemolytic anemia such as hydrops fetalis?

Dr. Sihan: If the mother is sensitized (raised antibody titer) and the fetus is suspected to be affected by the hemolytic anemia, termination of the pregnancy can be done considering the gestational age. If fetal evidence of hemolytic anemia is severe (hydrops fetalis), intrauterine blood transfusion is 
the treatment option. Intrauterine blood transfusion is usually done between 18 and 34 weeks of gestation as too early or late transfusion may cause the fetal demise. $\underline{13}$

Dr. Debashish Saha: What is the treatment modality of a newborn affected with Rh isoimmunization?

Dr. Sanjoy Kumer Dey: There are several options to treat the hemolytic anemia due to Rh isoimmunization in an infant. No intervention is required in mild cases. But if the hemolytic anemia is severe, then the infant requires double volume exchange transfusion through the umbilical cord to correct anemia and to get rid of antibodies. The procedure involves the slow removal of the newborn's blood and replacement with fresh blood from a donor. Phototherapy is another modality of jaundice in the newborn. $\underline{.11,14}$

The reduction of bilirubin with prompt and effecttive management is very crucial as it can cause irreversible brain damage and kernictarus or bilirubin encephalopathy if untreated.

Dr. Mohosina Afrin: Why rebound hyperbilirubinemia occurred in this newborn?

Dr. Dey: Rh isoimmunization is such a condition where varying degrees of ongoing hemolysis is observed.14 Rebound hyperbilirubinemia is the reflection of ongoing hemolysis in this particular case. So, frequent and close clinical and bilirubin monitoring are mandatory in a case of hemolytic disease of newborn due to Rh isoimmunization.

Dr. Iffat: If the mother had high anti-D titer, should we give anti-D after delivery of an affected baby?

Dr. Dey: If mother is already sensitized evidenced by rising antibody titer, the anti-D is no longer be helpful for the current pregnancy. But after delivery, anti-D should be administered to prevent isoimmunization for the next pregnancy.

Dr. Ismat Jahan Sheme: Is there any role of intravenous IgG while waiting for exchange transfusion?

Dr. Shabuj: According to the recent recommendation, intravenous IgG has a role in hemolytic disease of newborn as it decreases the rate of exchange transfusion in the affected newborn.15-17 Intravenous $\gamma$-globulin has proven its efficacy to decrease the need for exchange transfusion in the Rh hemolytic disease. $\underline{18}$

Dr. Poonam Bodh: How phototherapy lowers bilirubin level?

Dr. Sihan: Phototherapy lowers serum bilirubin level by using light energy and changing the shape and molecular structure of bilirubin, and converting it to such type of molecules that can be excreted easily in bile or urine. 19 After Absorption of phototherapy light by bilirubin, it induces the bilirubin pigment to undergo some photochemical reactions which occurs at varying degrees. After these photochemical reactions, they produce yellowish stereoisomers of bilirubin and some colorless products of low molecular weight. These products are less lipophilic than that of bilirubin, and they can be excreted in bile or urine and here conjugation is not needed.20,21 It's efficacy to lower bilirubin level is proven through several randomized clinical trial which was conducted between 1960 and 1990.22,23 Phototherapy also has its proven efficacy to reduce the number of Exchange transfusion in case of severe jaundice due to $\mathrm{Rh}$ isoimmunization. $.21,23-26$

Dr. Hanif Sumon: Is there any side effects of phototherapy?

Dr. Dey: There are no evidence of significant toxicity due to phototherapy in multiple trials. $\underline{27,28}$ But In case of baby presented with direct hyperbilirubinemia, phototherapy can cause bronze baby syndrome, which is characterized by the development of dark, grayish-brown discoloration of skin, serum and urine. $\underline{29,30}$

Dr. Mahbooba Akhter: What are side effects of doing exchange transfusion in a baby with Rh isoimmunization?

Dr. Sihan: There are several side effects including blood clot, bradycardia, cessation of respiration, low platelet count, hypoglycemia and hyponatremia. Most of the complications occur in preterm infant and baby who are severely ill. $\underline{31}$

\section{References}

1. Sapp MV, Bussel JB. Immune haemolytic anaemias. In: Paediatric hematology. Lilleyman JS (ed). 2nd ed. UK, Churchill Livingstone, 2010, pp 214-16.

2. Zipursky A, Pollck J, Neelands P, Chown B, Israels LG. The transplacental passage of foetal red blood cells and the pathogenesis of $\mathrm{Rh}$ immunisation during pregnancy. Lancet 1913; 2: 489-93.

3. Maheshwari A, Carlo WA. Blood disorders. In: Nelson Textbook of pediatrics. Kliegman RM (ed). 20th ed. Philadelphia, Saunders Elsevier, 2016, p 883.

4. Louis D, Oberoi S, Sundaram V, Trehan A. Isolated early onset anemia after $\mathrm{Rh}$ isoimmunisation: A unique presentation in 3 neonates. J Pediatr Hematol Oncol. 2010; 32: e230-32.

5. Geifman-Holtzman O, Wojtowycz M, Kosmas E, Artal R. Female alloimmunization with antibodies known to cause haemolytic disease. Obstet Gynecol. 2007; 89: 272-75.

6. Polsky M, Wojtowycz M, Kosmas E, Louis D. Female alloimmunization with antibodies known to cause haemolytic disease. Obstet Gynecol. 2009; 99: 277-81. 
7. Joseph KS, Kramer MS. The decline in Rh haemolytic disease: Should Rh prophylaxis get all the credit? Am J Public Health. 1998; 88: 209-15.

8. Hoque MM, Hossain MM, Hassan MQ, Uddin ASMN, Begum JA, Chowdhury MAK. Neonatal hyperbilirubinemia requiring exchange transfusion: Management and outcome. Bangladesh J Child Health. 2004; 28: 55-59.

9. Chowdhury $\mathrm{CH}$, Hasan MA, Yeasmin F. Outcome of neonatal hyperbilirubinemia in a tertiary care hospital in Bangladesh. Malays J Med Sci. 2010; 17: 40-44.

10. Hossain M, Begum M, Ahmed S, Absar MN. Causes, management and immediate complications of management of neonatal jaundice? A hospitalbased study. J Enam Med Coll. 2015; 5: 104-09.

11. Gomella TL, Cunningham MD, Eyal FG (eds). In: Neonatology: Management, procedures, on-call problems, diseases, and drugs. $7^{\text {th }}$ ed. USA, McGraw-Hill Education, 2013, p 849.

12. Routine non-invasive prenatal prediction of fetal RHD genotype in Canada: The time is here. J Obstet Gynaecol Can. 2017; 39: 366-73.

13. Klumper FJ, van Kamp IL, Vandenbussche FP, Meerman RH, Oepkes D, Scherjon SA, Eilers PH, Kanhai HH. Benefits and risks of fetal red-cell transfusion after 32 weeks gestation. Eur J Obstet Gynecol Reprod Biol. 2000; 92: 91.

14. Russel $A B$, Isaacs $D$. Infection in the newborn. In: Rennie \& Robertn's Textbook of neonatology. Rennie JM (ed). $5^{\text {th }}$ ed. UK, Churchil Livingstone Elsevier, 2012, p 1041.

15. Alcock GS, Liley H. Immunoglobulin infusion for isoimmune haemolytic jaundice in neonates. Cochrane Database Syst Rev. 2002, CD003313.

16. Gottstein R, Cooke RWI. Systemic review of intravenous immunoglobulin in haemolytic diseases of newborn. Arch Dis Child Fetal Neonatal Ed. 2003; 88: F6-F10.

17. American Academy of Pediatrics Subcommittee on hyperbilirubinemia. Management of hyperbilirubinemia in the newborn infant 35 or more weeks of gestation. Pediatrics 2004; 114: 297-316.

18. Gupta V, Bhatia B, Kumar A. Changing face of haemolytic anaemia in newborn. J Neonatol. 2011; 25: 76-81.

19. Maisels MJ, McDonagh AF. Phototherapy for neonatal jaundice. N Engl J Med. 2008; 358: 920-28.

20. Lightner DA, McDonagh AF. Molecular mechanisms of phototherapy for neonatal jaundice. Accts Chem Res. 1984; 17: 417-24.

21. Maisels MJ. Phototherapy: Traditional and nontraditional. J Perinatol. 2001; 21: S93-97.

22. Maisels MJ. Neonatal jaundice. In: Effective care of the newborn infant. Sinclair JC, Bracken MB (eds). Oxford, Oxford University Press, 1992: 507-61.

23. John E. Phototherapy in neonatal hyperbilirubinaemia. Aust Paediatr J. 1975; 11: 49-52.

24. Steiner LA, Bizzarro MJ, Ehrenkranz RA, Gallagher PG. A decline in the frequency of neonatal exchange transfusions and its effect on exchange-related morbidity and mortality. Pediatrics 2007; 120: 2732.

25. Patra K, Storfer-Isser A, Siner B, Moore J, Hack M. Adverse events associated with neonatal exchange transfusion in the 1990s. J Pediatr. 2004; 144: 626-31.

26. O'Shea TM, Dillard RG, Klinepeter KD, Goldstein DJ. Serum bilirubin levels, intracranial hemorrhage, and the risk of developmental problems in very low birth weight neonates. Pediatrics 1992; 90: 88892.

27. Maisels MJ. Phototherapy. In: Neonatal jaundice. Maisels MJ, Watchko JF (eds). Amsterdam, Harwood Academic Publishers, 2000, pp 177-203.

28. Jährig K, Jährig D, Meisel P (eds). Phototherapy: Treating neonatal jaundice with visible light. Munich, Quintessence Verlags-GmbH, 1993.

29. Kopelman AE, Brown RS, Odell GB. The bronze baby syndrome: A complication of phototherapy. J Pediatr. 1972; 81: 466-72.

30. Rubaltelli FF, Jori G, Reddi E. Bronze baby syndrome: A new porphyrin-related disorder. Pediatr Res. 1983; 17: 327-30.

31. Weisz B, Belson A, Milbauer B, Reif S. Complications of exchange transfusion in term and preterm newborn. Harefuah 1996; 130: 170-73. 